\title{
The clinical pattern of bronchial asthma in General Hospital, Kandy (Sri Lanka)
}

\author{
R. JEYRAJAH \\ M.B.B.S., M.R.C.P.(UK)
}

\author{
M. D. N. WICKRAMASINGHE
}

M.B.B.S.

Department of Medicine, University of Peradeniya, Peradeniya, Sri Lanka

\begin{abstract}
Summary
The clinical features and cutaneous hypersensitivity to skin prick tests were studied in 64 asthmatic patients in General Hospital, Kandy (Sri Lanka). The onset of asthma was mostly in adult life; associated atopic disease and family history of allergy were less frequent when compared with asthmatics in industrialised countries in the temperate zone. In these respects the clinical pattern of asthma in our study resembles that described in other tropical countries. Cutaneous hypersensitivity to one or more of the $\mathbf{1 0}$ allergens tested was observed in $75 \%$ of asthmatics and $55 \%$ of non-asthmatic controls. Although there was a higher incidence of associated allergic disorders, family history of allergy and the onset of asthma before the age of $\mathbf{1 0}$ years in the skin test positive group when compared with the skin test negative group of asthmatics, this difference was not statistically significant.
\end{abstract}

KEY WORDS: bronchial asthma, cutaneous hypersensitivity.

\section{Introduction}

Bronchial asthma is a common illness in the tropical countries and a major cause of out-patient attendance and admission (Mitchell, 1970; Buchanan and Jones, 1972). The clinical pattern of this illness in Zaria, Nigeria (Warrell et al., 1975) seems to differ in a few important aspects from that described in industrialised countries in the temperate zone in that it usually started in adult life and associated atopic disease and family history of allergy were uncommon. A high proportion of non-asthmatic control subjects in the tropics show cutaneous hypersensitivity to one or more allergens. This prompted us to study the clinical pattern and cutaneous hypersensitivity to skin prick tests in patients with bronchial asthma at General Hospital, Kandy (Sri Lanka).

\section{Patients and methods}

The 64 asthmatics studied consisted of those admitted to medical wards, either with a severe attack, or with a prolonged attack of asthma who failed to respond to treatment outside hospital, and those attending out-patient medical clinics with frequent attacks needing constant medication. The diagnosis of bronchial asthma was made on a history of paroxysmal, recurrent wheezy dyspnoea which was completely or partially reversible either spontaneously or with bronchodilator drugs. Variability of airways obstruction was observed during regular follow-up at the clinic with the help of history and physical examination. The group of 53 non-asthmatic control subjects studied were age and sex matched and did not have any evidence of obstructive airways disease on history and physical examination. The group consisted of 17 healthy volunteers and 36 patients admitted to the acute medical ward with various illnesses.

Each subject was interviewed and examined by one of the authors with the help of a questionnaire. Skin tests were done using a selected range of 10 allergens supplied by Bencard Laboratory Limited. The modified prick test method of Hendrick et al. (1975) was used. Glycero-saline was included as the control. Only immediate type 1 reactions were recorded. The wheal diameter was measured at 10 to 15 min using a transparent calibration plate. The diameter of any wheal produced by glycero-saline control was subtracted from the other results. Wheals of diameter $2 \mathrm{~mm}$ or more were regarded as positive (Pearson, 1973).

The control group of 53 non-asthmatics were also tested with the same 10 allergens. The $\chi^{2}$ test was done for statistical significance. Total and differential white blood cell counts were done in 57 asthmatics and 51 controls. Unconcentrated stool samples were examined for ova in 56 asthmatics and 42 nonasthmatics.

\section{Results}

The age in our group of 64 asthmatics ranged from 16 to 70 years with a mean age of 42.9 years. Twentyfive (39\%) were males. Mean age of onset of asthma was 26.3 years. In $18(28.1 \%)$ patients, the first attack 
TABLE 1. Positive skin prick tests $(\%)$ in 64 asthmatics and 53 controls

\begin{tabular}{lccc}
\hline Allergens & Asthmatics & Controls & $P$ \\
\hline House dust & 62.5 & 17.0 & $<0.05$ \\
House dust mite & 54.7 & 9.4 & $<0.05$ \\
Hay dust & 31.3 & 18.9 & NS \\
Mixed threshing & 42.2 & 22.6 & NS \\
Mixed moulds & 18.8 & 13.2 & NS \\
Cotton & 6.3 & 3.8 & NS \\
Kapok & 17.2 & 3.8 & NS \\
Dog & 23.4 & 7.5 & NS \\
Cow & 25.0 & 3.8 & $<0.05$ \\
Feathers & 23.4 & 15.1 & NS \\
Positive for one or more & & & \\
of the 10 allergens used & 75.0 & 54.7 & NS \\
\hline \multicolumn{2}{c}{ NS = not significant. } & &
\end{tabular}

of asthma occurred before the age of 20 years. There was a history of associated atopic disease, eczema in 3 $(4.7 \%)$ and allergic rhinitis in $19(29.7 \%)$. Twentythree (39.9\%) admitted to a family history of atopic disease mainly asthma. Among the control group of 53 non-asthmatics, one $(1.9 \%)$ admitted to a history of rhinitis and $4(7.5 \%)$ had a family history of allergic disorders.

Thirty-seven asthmatics (58\%) claimed allergy to one or more articles of food consumed, but challenge studies were not carried out. Cutaneous hypersensitivity to one or more allergens was observed in 48 $(75 \%)$ asthmatics and $29(54.7 \%)$ controls (Table 1 ). Positive skin prick test reaction to house dust related allergens (house dust and Dermatophagoides pteronyssinus) was observed in $42(66 \%)$ asthmatics and 11 (21\%) controls. Comparing the 48 skin test positive asthmatics with the skin test negative group of 16, we found a higher, but not statistically significant, incidence of associated allergic disorders, family history of allergy and the onset before the age of 10 years in the former (Table 2).

TABLE 2. Comparison of 48 skin test positive and 16 skin test negative asthmatics

\begin{tabular}{|c|c|c|c|}
\hline History & $\begin{array}{c}\text { Skin test } \\
\text { positive } \\
(\%)\end{array}$ & $\begin{array}{c}\text { Skin test } \\
\text { negative } \\
(\%)\end{array}$ & $P$ \\
\hline \multicolumn{4}{|l|}{ Associated allergic diseases } \\
\hline eczema & $3(6 \cdot 3)$ & 0 & NS \\
\hline Family history of allergy & $19(39.6)$ & $4(25)$ & NS \\
\hline \multicolumn{4}{|l|}{ Provoking factors } \\
\hline animals & $5(10 \cdot 4)$ & () & NS \\
\hline food & $32(66 \cdot 7)$ & $5(31 \cdot 3)$ & $<0.05$ \\
\hline Onset before 10 years of age & $10(20 \cdot 8)$ & $2(12.5)$ & NS \\
\hline
\end{tabular}

$\mathrm{NS}=$ not significant

Round worm or hook worm ova were found in 7 $(12.5 \%)$ of the stools of the 56 asthmatic patients examined and in $12(28.6 \%)$ of the 42 control subjects. The blood eosinophil counts were raised (above $400 / \mathrm{mm}^{3}$ ) in a significant percentage of asthmatics (64.9\%) as opposed to controls (33.3\%).

\section{Discussion}

In certain aspects, the clinical features of bronchia $b$ asthma in our study differ from those described in industrialised countries in the temperate zone (Table $\vec{e}$ $3)$. In Kandy, it starts mainly in adult life, and associated allergic disorders and family history of allergy appear less frequent. This pattern is similartao that described in Zaria, Nigeria (Warrell et al., 19\$\$ and New Guinea (Anderson, 1974).

Bronchial asthma has been divided into two varieties: extrinsic, in which external allergen can be demonstrated, and intrinsic in which it cannot. In patients with intrinsic asthma IgE is normal or low the symptoms usually begin in adult life, the asthma is chronic and continuous and there is less persona $\bar{P}$ and family history of allergic disorders when com pared with the extrinsic group. Hendrick et al. (1975)阜 found in a majority of skin test positive patients that the asthma started before the age of 10 years and $\mathrm{a}$ higher proportion had rhinitis and infantile eczems. than in skin test negative asthmatics.

The late onset of asthma, relatively less frequent personal and family history of allergic disorders ing the Kandy asthmatics fits in with the clinical patterno of temperate zone intrinsic asthma as intrinsic asthma tends to be more severe than the extrinsis variety. This pattern may be due to the fact that patients with more severe asthma come to thiso hospital.

A significantly higher proportion $(65.6 \%)$ of asth matics showed cutaneous hypersensitivity to house dust related allergens when compared to controls $(20.8 \%)$. In Zaria, (Warrell et al., 1975) cutaneou结 hypersensitivity to house-dust-related allergens was? observed in $58 \%$ of asthmatics and $8 \%$ of controls There was no difference in the type of housing an ${ }^{\circ}$ mattress used by asthmatics and controls in our studyत् which could have accounted for this difference in $\frac{\text { Dे }}{2}$ 
TABLE 3. Comparison of bronchial asthma in Kandy, in other tropical countries and in the United Kingdom

\begin{tabular}{|c|c|c|c|}
\hline Clinical features & $\begin{array}{c}\text { Kandy } \\
(\%)\end{array}$ & $\begin{array}{c}\text { Tropical } \\
\text { countries } \\
(\%)\end{array}$ & $\begin{array}{l}\text { United Kingdom } \\
\qquad(\%)\end{array}$ \\
\hline Onset before 20 years & $28 \cdot 1$ & $\begin{array}{l}31 \cdot 1, \text { Zaria } \\
\text { (Warrell et al., 1975) } \\
15 \cdot 5, \text { New Guinea } \\
\text { (Anderson, 1974) }\end{array}$ & $\begin{array}{l}53.4 \\
\text { (Williams and Williams, 1949) } \\
62.9 \\
\text { (Pepys, 1973) }\end{array}$ \\
\hline Associated eczema & $4 \cdot 7$ & $\begin{array}{l}\text { Nil, Zaria } \\
\text { (Warrell et al., 1975) } \\
5 \cdot 6, \text { Barbados } \\
5, \text { Libya } \\
\text { (Cua-Lim. 1970) }\end{array}$ & $\begin{array}{l}22 \\
26 \\
\text { (Wendrick et al., 1975) }\end{array}$ \\
\hline Associated rhinitis & $29 \cdot 7$ & $\begin{array}{l}\text { 27, Zaria } \\
\text { (Warrell et al., 1975) } \\
\text { 25, Singapore } \\
\text { (Warrell et al., 1975) }\end{array}$ & $\begin{array}{l}67 \\
\text { (Hendrick et al., 1975) } \\
74 \\
\text { (Pepys, 1973) }\end{array}$ \\
\hline Family history of allergy & 39.9 & $\begin{array}{l}\text { 25, Zaria } \\
\text { (Warrell et al., 1975) } \\
\text { 11, New Guinea } \\
\text { (Williams and Williams, 1949) }\end{array}$ & $\begin{array}{l}50 \\
\text { (Williams and Williams, 1949) }\end{array}$ \\
\hline \multicolumn{4}{|l|}{$\begin{array}{l}\text { Cutaneous hypersensitivity } \\
\text { to one or more allergens }\end{array}$} \\
\hline Asthmatics & 75 & $\begin{array}{l}\text { 87, Zaria } \\
\text { (Warrell, et al., 1975) } \\
\text { 100, Ibadan } \\
\text { 100, New Guinea } \\
\text { (Anderson, 1974) }\end{array}$ & $\begin{array}{l}78 \\
\text { (Pepys, 1973) } \\
84 \\
\text { (Hendrick et al., 1975) }\end{array}$ \\
\hline Non-asthmatic controls & $54 \cdot 7$ & $\begin{array}{l}51, \text { Zaria } \\
\text { (Warrell et al., 1975) } \\
\text { 19.1, New Guinea } \\
\text { (Anderson, 1974) }\end{array}$ & $\begin{array}{l}17 \\
\text { (Tanner-Warwick, 1971) }\end{array}$ \\
\hline $\begin{array}{l}\text { Skin prick test negative } \\
\text { to all allergens used }\end{array}$ & 25 & $\begin{array}{l}\text { 13, Zaria } \\
\text { (Warrell et al., 1975) }\end{array}$ & $\begin{array}{l}16 \\
\text { (Hendrick et al., 1975) } \\
22 \\
\text { (Pepys, 1973) }\end{array}$ \\
\hline
\end{tabular}

reactivity. Sixteen of our asthmatics failed to react to any of the 10 allergens used and in these the pattern of illness did not significantly differ from the rest of the skin test positive asthmatics (Table 2). It is possible that if a wider range of more appropriate allergens had been used, more patients would have been skin test positive.

The combination of positive history with a positive skin prick test has been found to be a reliable way of identifying the allergens in extrinsic asthma in England (Hendrick et al., 1975). In our group of 64 patients with severe asthma studied, though the clinical pattern of the illness resembles that of intrinsic asthma described in countries in the temperate zone, there is a high percentage of cutaneous hypersensitivity. This we feel could be due to environmental factors. Hence, performing skin prick tests in the tropics may not have the same significance as in the countries from the temperate zone.

\section{Acknowledgments}

We thank Mr Jeremy Wyatt for providing us with the allergens from Bencard Laboratory Limited and Miss M. Goonatilaka for typing the article.

\section{References}

ANDERSON, H.R. (1974) The epidemiological and allergic features of bronchial asthma in the New Guinea Highlands. Clinical Allergy, 4, 171.

BUCHANAN, D.J. \& JONES, I.G. (1972) Allergy to house dust mites in the tropics. British Medical Journal, 3, 764.

CUA-LiM, F. (1970) Clinical evaluation of bronchial asthma in Manila. Journal of Asthma Research, 8, 51.

Hendrick, D.J., Davies, R.J., D'SouzA, M.F. \& PePYS, J. (1975) An analysis of skin prick test reactions in 656 asthmatic patients. Thorax, 30, 2.

MitCHell, H.S. (1970) Bronchial asthma in Kenya. East African Medical Journal, 47, 142.

Pearson, R.S. (1973) Asthma in Barbados. Clinical Allergy, 3, 289.

PEPYS, J. (1973) Types of allergic reaction, Clinical Allergy, (Suppl.), $3,491$.

TURner-Warwick, M. (1971) Provoking factors in asthma. British Journal of Diseases of the Chest, 65, 1.

Warrell, D.A., Fawcett, I.W., Harrison, B.D.W., Agamah, A.J., IBU, J.O., POPE, H.M. \& MABERLEY, D.J. (1975) Bronchial asthma in the Nigerian Savanna region: a clinical and laboratory study of 106 patients with a review of literature on asthma in tropics. Quarterly Journal of Medicine, 44, 325.

WILliams, E.O. \& WILliAMS, G.E.O. (1949) The natural history of asthma: a review of 300 cases. British Medical Journal, 2, 897.

(Accepted 16 November 1982) 